\begin{tabular}{c|c|c}
\hline \hline $\begin{array}{c}\text { Vol. 411: 49-60, 2010 } \\
\text { doi: } 10.3354 / \text { meps08647 }\end{array}$ & $\begin{array}{c}\text { MARINE ECOLOGY PROGRESS SERIES } \\
\text { Mar Ecol Prog Ser }\end{array}$ & Published July 29 \\
\hline \hline
\end{tabular}

\title{
Increased irradiance reduces food quality of sea ice algae
}

\author{
E. Leu $^{1, *}$, J. Wiktor ${ }^{2}$, J. E. Søreide ${ }^{3}$, J. Berge ${ }^{3,4}$, S. Falk-Petersen ${ }^{1,5}$ \\ ${ }^{1}$ Norwegian Polar Institute, Polar Environmental Centre, 9296 Tromsø, Norway \\ ${ }^{2}$ Institute of Oceanology, Polish Academy of Sciences, Powstańców Warszawy 55, 81-712 Sopot, Poland \\ ${ }^{3}$ The University Centre in Svalbard, PO Box 156, 9171 Longyearbyen, Norway \\ ${ }^{4}$ Akvaplan-niva, Polar Environmental Centre, 9296 Tromsø, Norway \\ ${ }^{5}$ Department of Arctic and Marine Biology, Faculty of Biosciences, Fisheries and Economics, University of Tromsø, \\ 9037 Tromsø, Norway
}

\begin{abstract}
The accelerating decrease of Arctic sea ice substantially changes the growth conditions for primary producers, particularly with respect to light. This affects the biochemical composition of sea ice algae, which are an essential high-quality food source for herbivores early in the season. Their high nutritional value is related to their content of polyunsaturated fatty acids (PUFAs), which play an important role for successful maturation, egg production, hatching and nauplii development in grazers. We followed the fatty acid composition of an assemblage of sea ice algae in a high Arctic fjord during spring from the early bloom stage to post bloom. Light conditions proved to be decisive in determining the nutritional quality of sea ice algae, and irradiance was negatively correlated with the relative amount of PUFAs. Algal PUFA content decreased on average by $40 \%$ from April to June, while algal biomass (measured as particulate carbon, C) did not differ. This decrease was even more pronounced when algae were exposed to higher irradiances due to reduced snow cover. The ratio of chlorophyll a ( $\mathrm{chl}$ a) to $\mathrm{C}$, as well as the level of photoprotective pigments, confirmed a physiological adaptation to higher light levels in algae of poorer nutritional quality. We conclude that high irradiances are detrimental to sea ice algal food quality, and that the biochemical composition of sea ice algae is strongly dependent on growth conditions.
\end{abstract}

KEY WORDS: Fatty acid composition $\cdot$ PUFA $\cdot$ Ice algae $\cdot$ Irradiance $\cdot$ Arctic $\cdot$ Diatom $\cdot$ Stable isotopes

\section{INTRODUCTION}

An accelerating loss of sea ice in the Arctic has been observed during recent years (Stroeve et al. 2005, Comiso et al. 2008), together with a substantial loss of multi-year ice (Maslanik et al. 2007). This development has major implications for the underwater light climate and, hence, primary production in Arctic waters, since increasing areas of open water will lead to increased pelagic production (Arrigo et al. 2008). At the same time, the growth season for sea ice algae will become shorter (Cota et al. 1991), as they lose their substrate. In addition, they will probably be exposed to higher irradiances than before. Sea ice algae start growing early in the season and are adapted to extremely low irradiances (Johnsen \& Hegseth 1991), as indicated by, e.g., a high chl a:C ratio. Together with nutrient accessibility, irradiance has been identified as the most important environmental factor steering ice algal growth (Cota et al. 1991). Moreover, these factors largely determine algal nutritional quality in terms of fatty acid composition (Thompson et al. 1990, Reitan et al. 1994) and elemental stoichiometry (Sterner \& Elser 2002) with corresponding implications for higher trophic levels (Muller-Navarra 2008).

Microalgae living in or attached to the bottom of sea ice represent an important contribution to primary production in marine ecosystems at high latitudes (Arrigo 
2003). Even though estimates of their importance for overall annual primary production vary from $<1 \%$ in shallow coastal areas (Rysgaard \& Nielsen 2006) to $57 \%$ in the Arctic Ocean (Gosselin et al. 1997), their role for grazers can be crucial, since they are the only accessible food source early in the season (Conover et al. 1986, Runge \& Ingram 1988, Tourangeau \& Runge 1991, Michel et al. 1996). The availability of high quality food for grazers early in the season has far-reaching implications for an ecosystem that is strongly restricted in its productivity by extreme seasonality and limited access to light (due to solar angle, sea ice and snow cover). The importance of sea ice algae for grazers is determined not only by the amount of biomass produced but also by their quality. This is in particular true since sea ice algal spring blooms serve as an important food source for female grazers during their reproductive phase (Tourangeau \& Runge 1991, Søreide et al. 2010). Field and experimental studies have proven that essential polyunsaturated fatty acids (PUFAs) are important for successful egg production, hatching and larval development of zooplankton (Jonasdottir et al. 2005, 2009).

The fatty acid composition of algae depends strongly on their physiological state and, hence, the environmental conditions they are exposed to. For sea ice microalgae, growth conditions are intrinsically linked to the physical structure of the sea ice and overlying snow cover, and their seasonal changes (Mundy et al. 2005). At the same time, ice algae also alter the spectrum of photosynthetically active radiation (PAR, 400 to $700 \mathrm{~nm}$ ) transmitted through the ice. Apart from being essential for primary production, too high irradiance levels can be detrimental, especially under low temperatures (Mock \& Thomas 2005). In phytoplankton blooms, the highest relative amounts of PUFAs occur usually during the early phase of the bloom, often prior to the biomass peak (Skerratt et al. 1995, Reuss \& Poulsen 2002, Leu et al. 2006a). Algal PUFA content is negatively affected by high irradiances close to the surface under stratified conditions (Leu et al. 2006a, E. Leu unpubl. data). Field studies of temporal changes in the biochemical composition of sea ice algae are scarce, but some work has been done on seasonal changes in photosynthate allocation to different fractions of macromolecules (Smith et al. 1989, 1993, Lizotte \& Sullivan 1992). The relative allocation of photosynthetically fixed carbon to lipids usually increases towards the end of the ice algal growth season (Smith et al. 1993, Lee et al. 2008), as well as the relative content of storage lipids (mainly triacylglycerols, TAGs) compared to structural lipids (Smith et al. 1993). According to Smith et al. (1987), lipid allocation is particularly light-sensitive, compared to polysaccharide allocation. Experimental studies addressing the role of nutrients and light in the lipid and fatty acid composition of ice algae revealed an increase in storage lipid production under N-limitation (Mock \& Kroon 2002a), as well as a growing desaturation of chloroplast membrane lipids under light limitation (Mock \& Kroon 2002b). Especially low-light acclimated sea ice algae react to nutrient depletion and decreasing irradiances by increasing glycolipid production (Mock \& Gradinger 2000).

Biochemical changes in algae due to changing environmental conditions affect not only food quality parameters but also their isotope composition. Stable isotope signals have been applied widely, especially to identify the importance of algae as a food source for different grazers, and to follow their fate in the ecosystem. Ice algae are more enriched in ${ }^{13} \mathrm{C}$ than phytoplankton (Hobson et al. 1995, Søreide et al. 2006a), and since the ${ }^{13} \mathrm{C}$ values of consumers are only slightly enriched $(<1 \%$ ) relative to their diet, it is possible to follow ice algae versus phytoplankton carbon pathways in food webs (Hobson \& Welch 1992, Post 2002, Søreide et al. 2006a). However, large variations in ice algae stable carbon values exist (Søreide et al. 2006a, Gradinger 2009). Besides problems with contamination of small heterotrophic organisms, the stable isotope composition of ice algae changes according to the isotopic composition of their chemical environment (Fry 1996, Kennedy et al. 2002), although changes due to physiological differences cannot be excluded. At present, however, our knowledge is poor considering this last aspect.

A limited number of studies on sea ice algae in the Svalbard area have been carried out (Johnsen \& Hegseth 1991, Hegseth 1992, Falk-Petersen et al. 1998, Henderson et al. 1998); none of them, however, included a time-series of seasonal development, and most took place in the open sea areas in the Barents Sea.

As pointed out by Søreide et al. (2010), the timing of reproduction for key grazers in the Arctic pelagic system seems to be tightly linked to the peaks in essential PUFA production by primary producers. The aim of this study was therefore to understand how ice algal fatty acid composition varies over time during the spring productive period, and which environmental factors govern these changes, with a special focus on light. We present here for the first time data about the fatty acid composition of ice algae from early to late-bloom stage, and the steering factors behind the observed changes.

\section{MATERIALS AND METHODS}

Study area. During 2007, an extensive seasonal study of the high Arctic fjord Rijpfjorden (Nordaustlandet, Svalbard) was carried out. Land-based sampling 


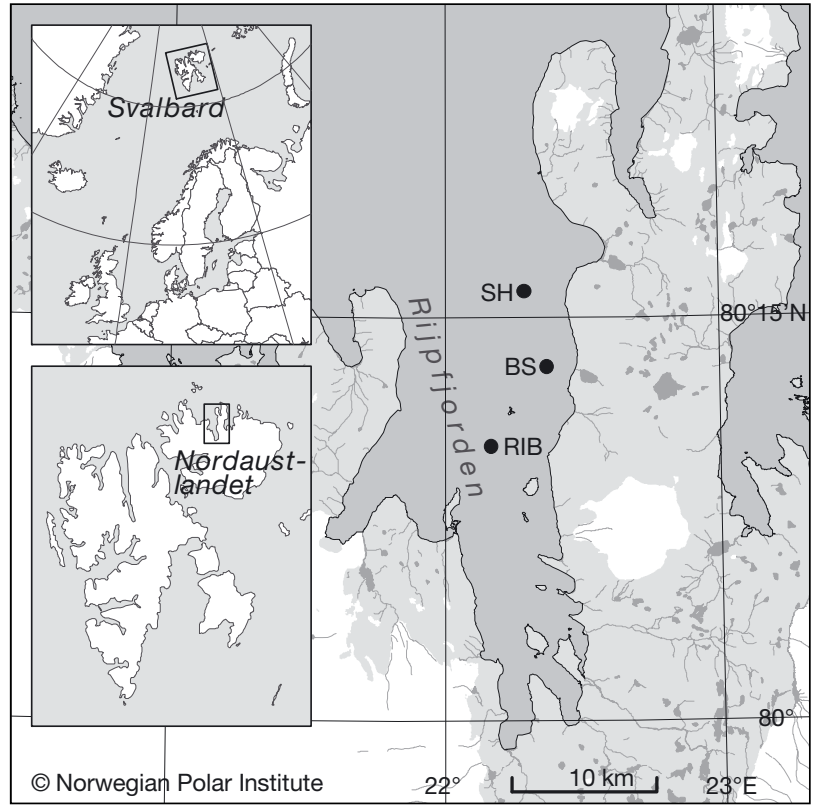

Fig. 1. Rijpfjorden, showing the locations of the main sampling stations ( $\mathrm{SH}, \mathrm{BS}, \mathrm{RIB})$

campaigns during spring took place in March (1 to 17), 21 April to May 4, June (4 to 10 ), and July ( 7 to 19 ). Rijpfjorden (Fig. 1) is approximately 30 nautical miles long and is located on the northern side of Nordaustlandet. It is an open fjord consisting of 2 separate basins (Ambrose et al. 2006), with a maximum depth of about $210 \mathrm{~m}$. The fjord has recently been the object of several investigations, and more details about its bathymetry and hydrography can be found in the studies by Wallace et al. (2010) and F. Cottier et al. (unpubl.). Two major sampling stations were established (see Fig. 1): one in the outer basin of the fjord $\left(\mathrm{SH}, 80^{\circ} 15.954^{\prime} \mathrm{N}, 22^{\circ} 17.397^{\prime} \mathrm{E}\right.$, depth: $\left.148 \mathrm{~m}\right)$, and another one in the inner basin (RIB, 80 $10.200^{\prime} \mathrm{N}$, $22^{\circ} 10.068^{\prime} \mathrm{E}$, depth: $175 \mathrm{~m}$ ). In addition, a shallow station (BS, $80^{\circ} 13.171^{\prime} \mathrm{N}, 22^{\circ} 22.341^{\prime} \mathrm{E}$, depth: $50 \mathrm{~m}$ ) on the ridge between the inner and the outer basin was sampled occasionally. In April and June, ice algae were sampled several times at all 3 stations, whereas in March, samples were taken only at another locality closer to the camp because of harsh weather conditions. In July, the sea ice had started to break up by the time of our arrival, and ice algae were completely washed out of thawing ice because of high temperatures of surface water. Therefore, biochemical data presented in this study stem mainly from April/May and June.

Measurements of ice thickness, snow depth and light conditions. Ice thickness and snow depth were determined at all sites from which ice cores for ice algae analyses were taken, as well as from the holes drilled for light measurements. Under-ice light measurements were carried out using a cosine-corrected underwater quantum sensor (LI-192, LI-COR), in combination with a surface reference sensor in air (LI-190, LI-COR) measuring incident radiation at the ice surface. Measurements were taken $1 \mathrm{~m}$ from the hole, first underneath an undisturbed site, and were then repeated in the same place after all snow was removed to determine the extent of light absorption caused by the snow cover.

Ice algae sampling. Quantitative samples of ice algae were obtained by using a SIPRE type corer of $12.5 \mathrm{~cm}$ diameter. Usually, 3 replicate cores were taken close to each other (approx. 50 to $100 \mathrm{~cm}$ apart) at each sampling site. The lowermost part of the core, containing a visible layer of ice algae (5 to $8 \mathrm{~cm}$ ), was cut off with a saw, protected carefully against light and transported quickly back to the camp. In the field laboratory, cores were thawed slowly in the dark (24 to $36 \mathrm{~h}$ ) using a thermobox, and $500 \mathrm{ml}$ of GF/F filtered seawater was added to prevent osmotic shock. All quantitative results given in this article are, however, corrected for this dilution. After complete thawing, subsamples of different volumes were filtered on pre-combusted GF/F filters for the determination of particulate carbon $(\mathrm{C})$, nitrogen $(\mathrm{N})$ and phosphorus $(\mathrm{P})$; photosynthetic pigment composition; and fatty acid composition of total lipids. Subsamples of 100 to $200 \mathrm{ml}$ were fixed with buffered formaldehyde and Lugol's solution (both $2 \%$ final concentration) for qualitative and quantitative analyses as well as cell size measurements. These measurements were carried out at the Institute of Oceanology of the Polish Academy of Sciences in Sopot under an inverted microscope (Nikon TM-300 at magnifications of $100 \times$ and $400 \times$ ), equipped with phase and interference contrasts and a camera system. The standard method by Utermöhl (1958) was applied. Diatoms and dinoflagellates were identified to the species or genus level, whereas other flagellates were identified to family, or noted as unidentified. Biomasses $\left(\mu \mathrm{gC} \mathrm{m}^{-2}\right)$ of dominating taxa were calculated according to geometrical measurements obtained during the microscopic analyses or from the Institute's own database. Different conversion factors were used for diatoms and non-diatom protist species, following the equations by Menden-Deuer \& Lessard (2000).

Fatty acid and stable isotope analysis. Samples of 100 to $200 \mathrm{ml}$ each from every ice core were filtered onto pre-combusted glass fibre filters (GF/F). For fatty acid analyses the filters were transferred to glass vials with Teflon-lined caps, and $8 \mathrm{ml}$ dichloromethanemethanol $(2: 1, \mathrm{v} / \mathrm{v})$ were added. The vials were stored at $-80^{\circ} \mathrm{C}$ until analysis. Total lipid was extracted according to the procedure described by Folch et al. (1957). A known amount of heneicosanoic acid (21:0) was added as an internal standard, and an acid- 
catalysed transesterification was carried out with $1 \%$ sulfuric acid in methanol (Christie 1982). For a detailed description of analysis by gas chromatography, see Leu et al. (2007). For stable isotope analyses the filters were kept frozen at $-80^{\circ} \mathrm{C}$ until analysis. Stable carbon and nitrogen isotope analyses were performed at the Institute for Energy Technology, Kjeller, Norway, as described by Søreide et al. (2006b), and included removal of both inorganic carbon and lipids before analysis. Stable isotope values are expressed in $\delta$ notation as the deviation from standards in parts per thousand (\%) according to Eq. (1):

$$
\delta X=\left[\left(R_{\text {sample }} / R_{\text {standard }}\right)-1\right] \times 1000
$$

where $X$ is ${ }^{13} \mathrm{C}$ or ${ }^{15} \mathrm{~N}$ and $R$ is the corresponding ratio ${ }^{13} \mathrm{C} /{ }^{12} \mathrm{C}$ or ${ }^{15} \mathrm{~N} /{ }^{14} \mathrm{~N}$. International standards USGS-24, calibrated against PeeDee Belemnite (Vienna) for ${ }^{13} \mathrm{C}$, and IAEA-N-1 and IAEA-N-2, calibrated against atmospheric $\mathrm{N}_{2}$ for ${ }^{15} \mathrm{~N}$, were used to determine $R_{\text {standard }}$.

Photosynthetic pigments. Samples from each core were taken for a complete analysis of all photosynthetic pigments by high performance liquid chromatography (HPLC). Usually $50 \mathrm{ml}$ of the thawed ice core were filtered onto GF/F filters. The filters were put in liquid nitrogen $\left(-196^{\circ} \mathrm{C}\right)$ and later stored at $-80^{\circ} \mathrm{C}$. The pigments were extracted in $1.5 \mathrm{ml} 100 \%$ $\mathrm{MeOH}$. The further analysis was done as described by Leu et al. (2006a). Pigments are expressed as ratios to chl a (by weight).

Elemental stoichiometry. Samples for analysis of particulate $\mathrm{C}, \mathrm{N}$, and $\mathrm{P}$ were taken from each core. Volumes of $20 \mathrm{ml}$ (100 $\mathrm{ml}$ for low biomass cores) were filtered onto pre-combusted $\left(1 \mathrm{~h}, 450^{\circ} \mathrm{C}\right) \mathrm{GF} / \mathrm{F}$ filters. All samples were stored at $-20^{\circ} \mathrm{C}$ until analysis. Particulate $\mathrm{C}$ and $\mathrm{N}$ were analysed on a Thermo Finnigan FlashEA 1112 elemental analyser. Particulate P analyses consisted of placing the filters in $15 \mathrm{ml}$ distilled water that was acidified (150 $\left.\mu \mathrm{l}, 4.0 \mathrm{M} \mathrm{H}_{2} \mathrm{SO}_{4}\right)$, adding peroxodisulfate (0.15 $\left.\mathrm{g} \mathrm{K}_{2} \mathrm{~S}_{2} \mathrm{O}_{8}\right)$, and autoclaving $\left(121^{\circ} \mathrm{C}, 1 \mathrm{~h}\right)$. The particulate fraction of $\mathrm{P}$ was then analysed spectrophotometrically by the standard ammonium-molybdate method (Hessen et al. 2002).

Nutrient analysis. Surface water samples for nutrients were taken by a Niskin bottle that was lowered just below the water surface in a freshly made hole at the same sites at which the bottom communities were sampled. Samples were stored frozen until analysis. Nutrients (nitrate, nitrite, silicate and phosphate) were analysed in non-filtered samples by standard seawater methods using a Flow Solution IV analyzer from OI Analytical. The analyzer was calibrated using reference seawater from OSIL Environmental Instruments and Systems.

Statistical analyses. To determine which environmental variables could best explain the variability in ice algae fatty acid composition, a multivariate direct gradient analysis (Redundancy Analysis, RDA), in the CANOCO software 4.5 package for Windows (ter Braak \& Smilauer 2002) was performed. RDA is a multivariate form of regression analysis in which, in this case, ice algae fatty acids (FA) and potential explanatory variables were analysed simultaneously to determine which of the explanatory variables best explained the FA variability. To estimate the proportion of variance in the fatty acid composition (\%) of sea ice algae that can be explained by a linear combination of predictor variables (called environmental variables in CANOCO), a multivariate direct gradient analysis (RDA) was performed, using the CANOCO software 4.5 for Windows (ter Braak \& Smilauer 2002). A detailed description of this method can be found in the study by Legendre \& Legendre (1998). Fatty acids accounting for $<1 \%$ in all samples were removed from the data set before analysis, without re-calculating the percentages of the remaining fatty acids. Non-transformed percentage values were used in all analyses. In the RDA, the samples and fatty acids were assigned scores on ordination axes, of which the first 2 axes are shown in the ordination biplot. Environmental variables are represented by arrows, pointing in the direction of maximum variance accounted for by the respective variable. The Monte-Carlo-permutation test was run with 9999 permutations, restricted for splitplot design, with a whole plot consisting of the samples taken on the same day. Whole plots were chosen to be freely exchangeable in the permutation test, while no permutation was allowed on the split-plot level. The marginal effects for all environmental variables were tested, but only the significant ones $(p<0.05)$ were included in the model by stepwise selection. The overall significance of the model was tested in another Monte-Carlo-permutation test on the first canonical axis with 9999 permutations, restricted for split-plot design as described above.

For testing differences in single variables between months or sites of different transmittance, $t$-tests were applied, given that variances were homogenous (tested with Levene's test). If they were not, a nonparametric Mann-Whitney $U$-test was used. For all tests, the threshold for significance was set at $\mathrm{p}<0.05$. All univariate analyses were carried out using STATISTICA 7.0 (StatSoft).

\section{RESULTS}

\section{Ice cover and snow depth}

During the first days of February, the entire fjord became covered by land-fast first year ice. Ice thick- 
ness measured in early to mid March ranged from 50 to $70 \mathrm{~cm}$. Until the end of April, the average ice thickness had increased to about $100 \mathrm{~cm}$ at Stns SH and BS, and to $78 \mathrm{~cm}$ in RIB. The same ice thickness distribution was found in early June. The snow cover, however, changed more dynamically. Due to snowfall during the sampling period in April, the snow depth at $\mathrm{SH}$ increased from 11 to almost $20 \mathrm{~cm}$ within a few days, and the greatest snow depth was found at the inner basin station $(24 \mathrm{~cm})$. In June, the snow conditions were entirely different and characterized by a very patchy distribution of old snow on the sea ice, leading to a highly heterogeneous situation. Sites with almost no snow $(<5 \mathrm{~cm})$ were found close to sites with up to $20 \mathrm{~cm}$ of snow, especially at Stns RIB and BS.

\section{Under-ice irradiances/transmittance}

In April, under cloudless conditions, incident PAR irradiances reached $800 \mu \mathrm{mol} \mathrm{m} \mathrm{m}^{-2} \mathrm{~s}^{-1}$ around noon. Irradiances underneath the ice (covered by snow), however, were very low, with the highest value measured at $\mathrm{SH}\left(3 \mu \mathrm{mol} \mathrm{m} \mathrm{m}^{-2} \mathrm{~s}^{-1}\right.$, Fig. 2), which corresponds

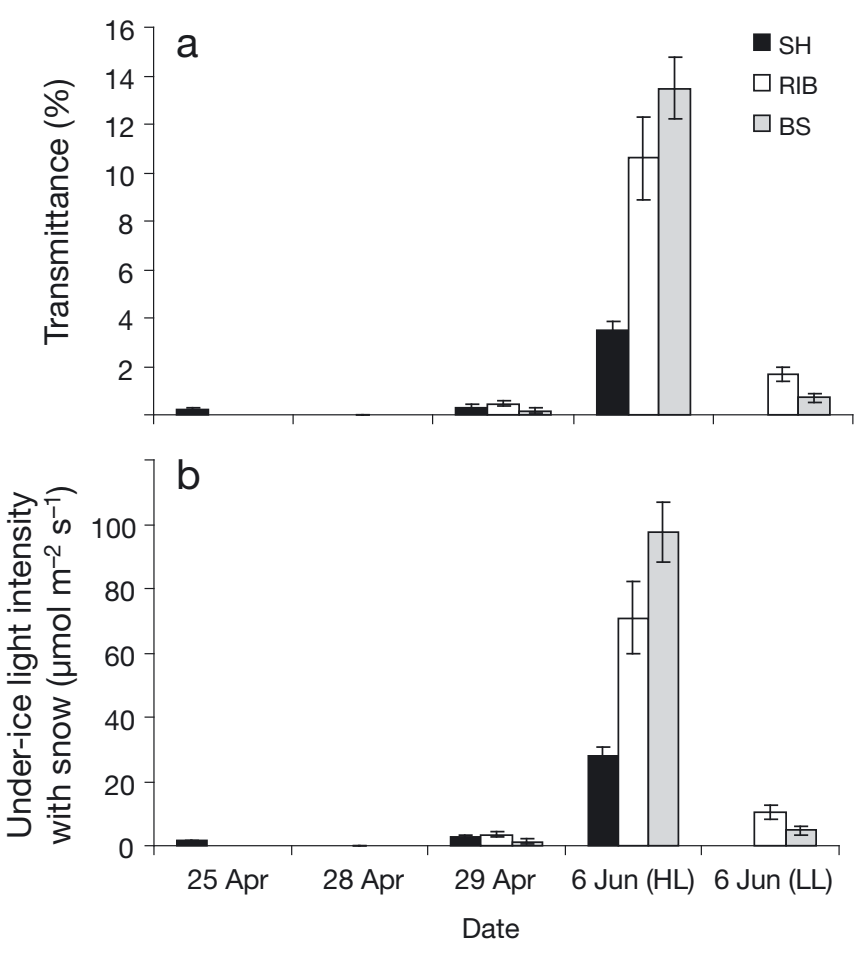

Fig. 2. Changes in (a) transmittance of ice and snow (\% of incident irradiance) and (b) in situ PAR irradiances measured around noon under the ice with a cosine-corrected LiCor Sensor. Presented are average values and standard deviations from measurements of 3 spots at $1 \mathrm{~m}$ from a drilled hole. $\mathrm{SH}$, RIB, BS: sampling sites (detailed locations are given in 'Materials and methods'). HL = High Light; LL = Low Light to transmittance values of less than $0.5 \%$. After removal of the snow, the highest measured irradiances underneath the ice were around $20 \mu \mathrm{mol} \mathrm{m} \mathrm{m}^{-2} \mathrm{~s}^{-1}$. In June, maximum incident PAR irradiances were only slightly higher than in April $\left(860 \mu \mathrm{mol} \mathrm{m}^{-2} \mathrm{~s}^{-1}\right)$, but the snow cover on the sea ice had changed substantially. We found areas with a lot of snow (approx. $20 \mathrm{~cm}$ ) and hard ice (named LL [Low Light] site) very close to virtually snow-free areas (approx. $4 \mathrm{~cm}$ ) with much softer ice (HL [High Light] site) due to melting and snowdrift. The ice thickness was similar at both sites. The underice irradiances, however, differed widely: while almost $100 \mu \mathrm{mol} \mathrm{m}{ }^{-2} \mathrm{~s}^{-1}$ had already been detected at the HL site before removing the snow, only 4 to $5 \mu \mathrm{mol} \mathrm{m}{ }^{-2} \mathrm{~s}^{-1}$ penetrated through the ice at the LL site. Removing the snow at both places resulted in an increase in underice irradiances to 126 and $36 \mu \mathrm{mol} \mathrm{m} \mathrm{m}^{-2} \mathrm{~s}^{-1}$, respectively (Fig. 2). For the LL site, this represents an almost 10 -fold increase in irradiance due to snow removal. A similar situation was found in the inner basin at RIB, where under-ice irradiances with snow ranged from 10 to $70 \mu \mathrm{mol} \mathrm{m} \mathrm{m}^{-2} \mathrm{~s}^{-1}$, and after snow removal from 73 to $120 \mu \mathrm{mol} \mathrm{m}{ }^{-2} \mathrm{~s}^{-1}$.

\section{Fatty acid composition}

The fatty acid composition of ice algae was characterized by high amounts of PUFAs by the end of April. At all 3 sampling stations, PUFAs accounted for 35 to $40 \%$ of total fatty acids, while the relative amount of saturated fatty acids (SAFAs) was similar (between 35 and $38 \%$ ) (Table 1). Monounsaturated fatty acids (MUFAs) were mainly represented by 16:1n7 and accounted for 26 to $28 \%$. Diatom biomarkers, such as 20:5n3 and C16 PUFAs, were prevailing among the PUFAs and accounted for almost $1 / 2$ and $1 / 3$ of the total amount of PUFAs, respectively. Furthermore, 18:4n3 and 22:6n3 accounted for roughly 3\% PUFAs each. By contrast, ice algal fatty acid composition in June was dominated by MUFAs (almost exclusively $16: 1 \mathrm{n} 7$ ), accounting for 44 to $53 \%$ of total fatty acids. By June, PUFAs had decreased substantially and made up only 18 to $28 \%$ of total fatty acids. More than half of this was attributed to $20: 5 \mathrm{n} 3$ in all samples. Interestingly, a clear difference between the HL and LL sites at the same sampling station was found; the HL sites with little snow on top were characterized by lower relative amounts of PUFAs and higher 16:1n7 and 16:0 (Table 1). This difference was more pronounced at Stn BS (where also the irradiance difference was greatest between HL and LL). The sum of SAFAs at all stations accounted for 28 to $31 \%$, not showing any clear differences between HL and LL sites. An RDA of the fatty acid composition of all samples showed 3 
groups of samples that can be distinguished on the basis of their fatty acid profiles: (1) all samples taken in April, (2) June HL samples, and (3) June LL samples (Fig. 3). The environmental factor transmittance ex- plained $36 \%$ of the variability in the data set. Since the other environmental factors were strongly correlated with transmittance (chla:C, under-ice irradiance, (diadinoxanthin $[\mathrm{Dd}]+$ diatoxanthin $[\mathrm{Dt}])$ : chl $a, \mathrm{C}: \mathrm{N}$,

Table 1. Fatty acid composition of total lipids for sea ice algae. Shown are means and SD for 3 replicate ice cores. Fatty acids accounting for $<1 \%$ of total fatty acids in all samples are not displayed in the table. SH, RIB, BS: sampling sites (detailed locations are given in 'Materials and methods'). LL = Low Light; HL = High Light. PUFA: polyunsaturated fatty acids; MUFA: monounsaturated fatty acids; SAFA: saturated fatty acids

\begin{tabular}{|c|c|c|c|c|c|c|c|c|c|}
\hline & $\begin{array}{c}\text { SH } \\
26 \mathrm{Apr}\end{array}$ & $\begin{array}{c}\text { RIB } \\
28 \mathrm{Apr}\end{array}$ & $\begin{array}{c}\text { BS } \\
28 \mathrm{Apr}\end{array}$ & $\begin{array}{c}\text { SH } \\
30 \mathrm{Apr}\end{array}$ & $\begin{array}{c}\mathrm{SH} \\
5 \mathrm{Jun}\end{array}$ & $\begin{array}{l}\text { BS (LL) } \\
6 \text { Jun }\end{array}$ & $\begin{array}{l}\text { BS (HL) } \\
6 \text { Jun }\end{array}$ & $\begin{array}{l}\text { RIB (LL) } \\
7 \text { Jun }\end{array}$ & $\begin{array}{l}\text { RIB (HL) } \\
7 \text { Jun }\end{array}$ \\
\hline $14: 0$ & $7.8 \pm 0.7$ & $6.8 \pm 1.1$ & $8.2 \pm 2.6$ & $8.5 \pm 0.2$ & $8.7 \pm 0.3$ & $8.6 \pm 0.5$ & $8.4 \pm 0.4$ & $6.9 \pm 0.7$ & $6.9 \pm 0.3$ \\
\hline $15: 0$ & $0.7 \pm 0.0$ & $0.5 \pm 0.1$ & $0.8 \pm 0.0$ & $0.7 \pm 0.1$ & $0.6 \pm 0.2$ & $0.4 \pm 0.0$ & $0.4 \pm 0.0$ & $0.4 \pm 0.0$ & $0.4 \pm 0.0$ \\
\hline 16:0 Pristanic & $4.9 \pm 0.8$ & $4.4 \pm 0.8$ & $5.4 \pm 0.8$ & $5.8 \pm 0.2$ & $1.6 \pm 0.4$ & $2.1 \pm 0.5$ & $0.1 \pm 0.2$ & $0.6 \pm 0.2$ & $0.1 \pm 0.5$ \\
\hline $16: 0$ & $16.5 \pm 0.4$ & $15.7 \pm 0.9$ & $16.8 \pm 2.7$ & $15.0 \pm 1.4$ & $17.7 \pm 1.7$ & $13.9 \pm 2.0$ & $19.5 \pm 0.5$ & $18.9 \pm 1.3$ & $20.2 \pm 0.9$ \\
\hline $16: 1 \mathrm{n} 9$ & $0.7 \pm 0.2$ & $0.4 \pm 0.2$ & $0.4 \pm 0.2$ & $0.4 \pm 0.1$ & $0.2 \pm 0.0$ & $0.2 \pm 0.1$ & $0.2 \pm 0.0$ & $0.2 \pm 0.0$ & $0.2 \pm 0.0$ \\
\hline $16: 1 \mathrm{n} 7$ & $18.0 \pm 2.2$ & $19.9 \pm 10.5$ & $20.4 \pm 11.6$ & $18.7 \pm 4.4$ & $42.0 \pm 5.7$ & $41.4 \pm 1.5$ & $49.2 \pm 1.9$ & $48.0 \pm 1.3$ & $50.2 \pm 0.3$ \\
\hline $16: 1 \mathrm{n} 5$ & $0.9 \pm 0.2$ & $0.9 \pm 0.3$ & $0.8 \pm 0.3$ & $0.6 \pm 0.0$ & $0.5 \pm 0.1$ & $0.6 \pm 0.1$ & $0.3 \pm 0.0$ & $0.3 \pm 0.0$ & $0.3 \pm 0.0$ \\
\hline $16: 2 \mathrm{n} 7$ & $2.5 \pm 0.3$ & $2.6 \pm 0.2$ & $2.6 \pm 0.2$ & $2.6 \pm 0.3$ & $1.4 \pm 0.2$ & $1.6 \pm 0.3$ & $0.8 \pm 0.1$ & $0.9 \pm 0.1$ & $0.8 \pm 0.1$ \\
\hline $16: 3 n 4$ & $2.6 \pm 0.2$ & $3.4 \pm 1.2$ & $2.8 \pm 1.2$ & $2.6 \pm 0.5$ & $1.2 \pm 0.1$ & $1.7 \pm 0.4$ & $0.4 \pm 0.0$ & $0.7 \pm 0.0$ & $0.4 \pm 0.1$ \\
\hline $16: 4 \mathrm{n} 1$ & $6.0 \pm 0.5$ & $6.4 \pm 0.7$ & $5.3 \pm 0.9$ & $5.8 \pm 1.4$ & $3.3 \pm 0.2$ & $3.7 \pm 0.4$ & $1.4 \pm 0.1$ & $2.4 \pm 0.1$ & $1.6 \pm 0.2$ \\
\hline $17: 0$ & $1.2 \pm 0.1$ & $1.0 \pm 0.2$ & $1.0 \pm 0.3$ & $1.0 \pm 0.2$ & $0.5 \pm 0.1$ & $0.5 \pm 0.1$ & $0.2 \pm 0.0$ & $0.3 \pm 0.0$ & $0.3 \pm 0.0$ \\
\hline $18: 0$ & $2.2 \pm 1.5$ & $3.1 \pm 1.8$ & $3.0 \pm 2.7$ & $3.1 \pm 0.4$ & $1.0 \pm 0.3$ & $0.9 \pm 0.3$ & $1.0 \pm 0.2$ & $0.8 \pm 0.2$ & $1.0 \pm 0.1$ \\
\hline $18: 1 \mathrm{n} 9$ & $3.5 \pm 1.4$ & $3.2 \pm 2.1$ & $2.6 \pm 1.5$ & $3.6 \pm 0.8$ & $0.7 \pm 0.1$ & $0.5 \pm 0.0$ & $1.2 \pm 0.3$ & $1.2 \pm 0.3$ & $1.7 \pm 0.3$ \\
\hline $18: 2 \mathrm{n} 6$ & $1.2 \pm 0.4$ & $0.9 \pm 0.2$ & $0.8 \pm 0.2$ & $0.9 \pm 0.0$ & $0.4 \pm 0.1$ & $0.4 \pm 0.0$ & $0.5 \pm 0.0$ & $0.4 \pm 0.1$ & $0.6 \pm 0.0$ \\
\hline $18: 3 n 3$ & $0.6 \pm 0.1$ & $0.6 \pm 0.3$ & $0.9 \pm 0.8$ & $0.5 \pm 0.0$ & $0.3 \pm 0.1$ & $0.4 \pm 0.3$ & $0.3 \pm 0.0$ & $0.3 \pm 0.1$ & $0.4 \pm 0.0$ \\
\hline $18: 4 n 3$ & $3.9 \pm 0.3$ & $3.2 \pm 0.4$ & $2.7 \pm 0.2$ & $3.4 \pm 0.2$ & $1.3 \pm 0.4$ & $1.0 \pm 0.1$ & $0.9 \pm 0.1$ & $1.1 \pm 0.0$ & $1.5 \pm 0.0$ \\
\hline $20: 5 n 3$ & $16.4 \pm 0.7$ & $17.1 \pm 1.7$ & $16.5 \pm 1.1$ & $17.9 \pm 2.5$ & $13.5 \pm 1.2$ & $16.1 \pm 1.2$ & $11.1 \pm 0.7$ & $12.5 \pm 3.6$ & $10.1 \pm 0.6$ \\
\hline $22: 0$ & $1.2 \pm 0.3$ & $1.4 \pm 1.0$ & $0.9 \pm 0.8$ & $0.8 \pm 0.3$ & $0.4 \pm 0.1$ & $0.5 \pm 0.2$ & $0.2 \pm 0.0$ & $0.3 \pm 0.1$ & $0.2 \pm 0.0$ \\
\hline $22: 6 n 3$ & $3.2 \pm 0.0$ & $2.7 \pm 0.5$ & $2.7 \pm 0.6$ & $2.9 \pm 0.3$ & $1.7 \pm 0.2$ & $1.9 \pm 0.3$ & $1.1 \pm 0.1$ & $1.2 \pm 0.1$ & $1.2 \pm 0.1$ \\
\hline PUFA & $37.7 \pm 0.4$ & $38.0 \pm 4.4$ & $35.4 \pm 4.9$ & $37.5 \pm 4.2$ & $24.5 \pm 2.6$ & $28.1 \pm 2.6$ & $18.2 \pm 0.9$ & $20.8 \pm 3.4$ & $17.5 \pm 1.0$ \\
\hline MUFA & $25.9 \pm 0.8$ & $27.1 \pm 6.8$ & $26.6 \pm 8.6$ & $25.8 \pm 3.6$ & $44.3 \pm 5.3$ & $43.9 \pm 1.3$ & $51.7 \pm 2.0$ & $50.4 \pm 1.4$ & $53.1 \pm 0.2$ \\
\hline SAFA & $36.4 \pm 1.2$ & $34.9 \pm 2.5$ & $37.9 \pm 3.8$ & $36.7 \pm 1.1$ & $31.2 \pm 3.0$ & $28.0 \pm 1.5$ & $30.1 \pm 1.4$ & $28.8 \pm 2.3$ & $29.4 \pm 0.8$ \\
\hline
\end{tabular}

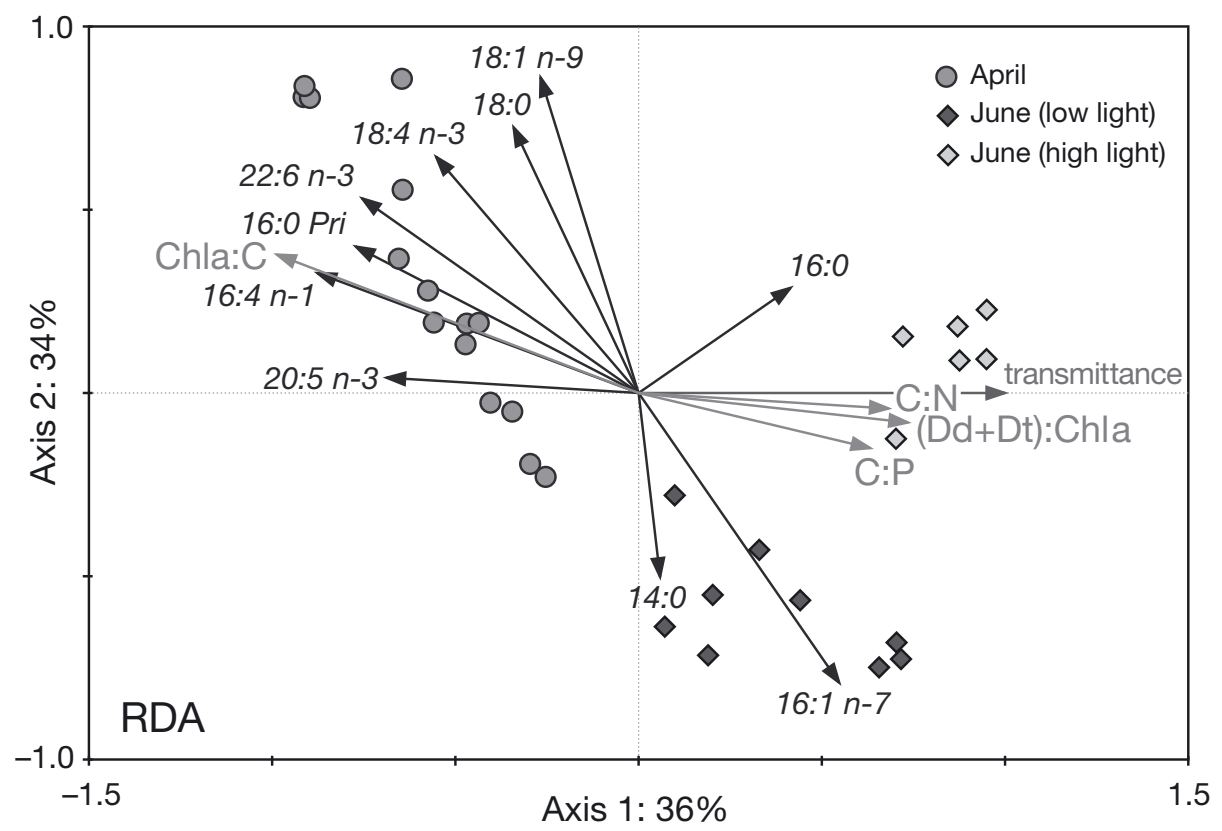

Fig. 3. Results of the redundancy analysis (RDA) of ice algal fatty acid composition sampled in Rijpfjorden from April to June 2007. Passive variables shown in the plot: ratio between chlorophyll $a$ and particulate carbon (chl $a$ :C), ratios between $\mathrm{C}$ and particulate nitrogen $(\mathrm{N})$ and phosphorus $(\mathrm{P})$, ratio between the sum of diadinoxanthin and diatoxanthin, and chl $a([\mathrm{Dd}+\mathrm{Dt}]: \mathrm{Chl} a)$ 
$\mathrm{C}: \mathrm{P})$, they added little to the explanatory power of the model and were therefore not included in the final analysis. The significance of the model was tested for the first canonical axis and proved to be highly significant ( $F$-value: 16.532; $\mathrm{p}<0.001)$.

\section{Nutrient values, elemental stoichiometry and stable isotope ratios}

High (winter) nutrient concentrations were found in surface water under the ice from March to June (Fig. 4). Values for March were a little lower and more variable than those from the other months. A slight reduction in nitrate was found between March-May (8 to $10 \mu \mathrm{mol}$ $\left.\mathrm{l}^{-1}\right)$ and June $\left(7 \mu \mathrm{mol} \mathrm{l}^{-1}\right)$, as well as a small decrease in phosphate concentrations $\left(0.5 \mu \mathrm{mol}^{-1}\right.$ in June vs. 0.6 to $0.7 \mathrm{~mol} \mathrm{l}^{-1}$ in March/April). Silicate concentrations remained largely unaltered. Between June and July, a major depletion of nutrients was observed, principally of nitrate which was consumed to levels below detection limit, while silicate and phosphate were reduced by more than $50 \%$ (Fig. 4).

Molar ratios of $\mathrm{C}: \mathrm{N}$ in particulate matter collected from sea ice ranged from 10 to 16 in April and from 11.5 to 18 in June (Table 2). The average ratio in April $(12.4 \pm 2.6)$ was significantly lower than that in June $(14.64 \pm 2.9$; $t$-test: $\mathrm{p}<0.05)$. Samples from June that were exposed to lower irradiances (LL-sites) compared with those exposed to higher irradiances (HL-sites) had a significantly lower $\mathrm{C}: \mathrm{N}$ ratio: on average only $12.7 \pm 1.7$ vs. $17.6 \pm 1.7$ ( $t$-test: $p<0.01)$. Molar ratios of $\mathrm{C}: \mathrm{P}$ were also found to be on average higher in June than in April $(132 \pm 21$ vs. $101 \pm 26$, $t$-test: $p<0.001)$, whereas no significant difference between LL- and HL-sites in June was detectable in these ratios. N:P ratios did not differ significantly between April and June or between sites with different irradiance. The average values ranged from 8.3 to 9.7 (Table 2).

The stable isotope ratios for ice algae ranged from -23.1 to $-21.0 \%$ for $\delta^{13} \mathrm{C}$ and from 3.3 to $4.3 \%$ for $\delta^{15} \mathrm{~N}$ in April (Table 3). In June, ice algae were on average $4.5 \%$ more enriched in ${ }^{13} \mathrm{C}$ than in April ( $t$-test, $\mathrm{p}<$ 0.001) (Table 3). In comparison, ice algae were only slightly more enriched in ${ }^{15} \mathrm{~N}$ in June than in April (mean $4.8 \pm 0.7$ vs. mean $3.5 \pm 1.2 \%$, $\mathrm{p}=0.024$ ).

\section{Sea ice protists: community composition, biomass and photoprotective pigments}

Sea ice protist assemblages were dominated by diatoms accounting for 70 to $99 \%$ of cell abundances in all samples, with a higher contribution of non-diatoms in June than in April. Nitzschia frigida, Navicula

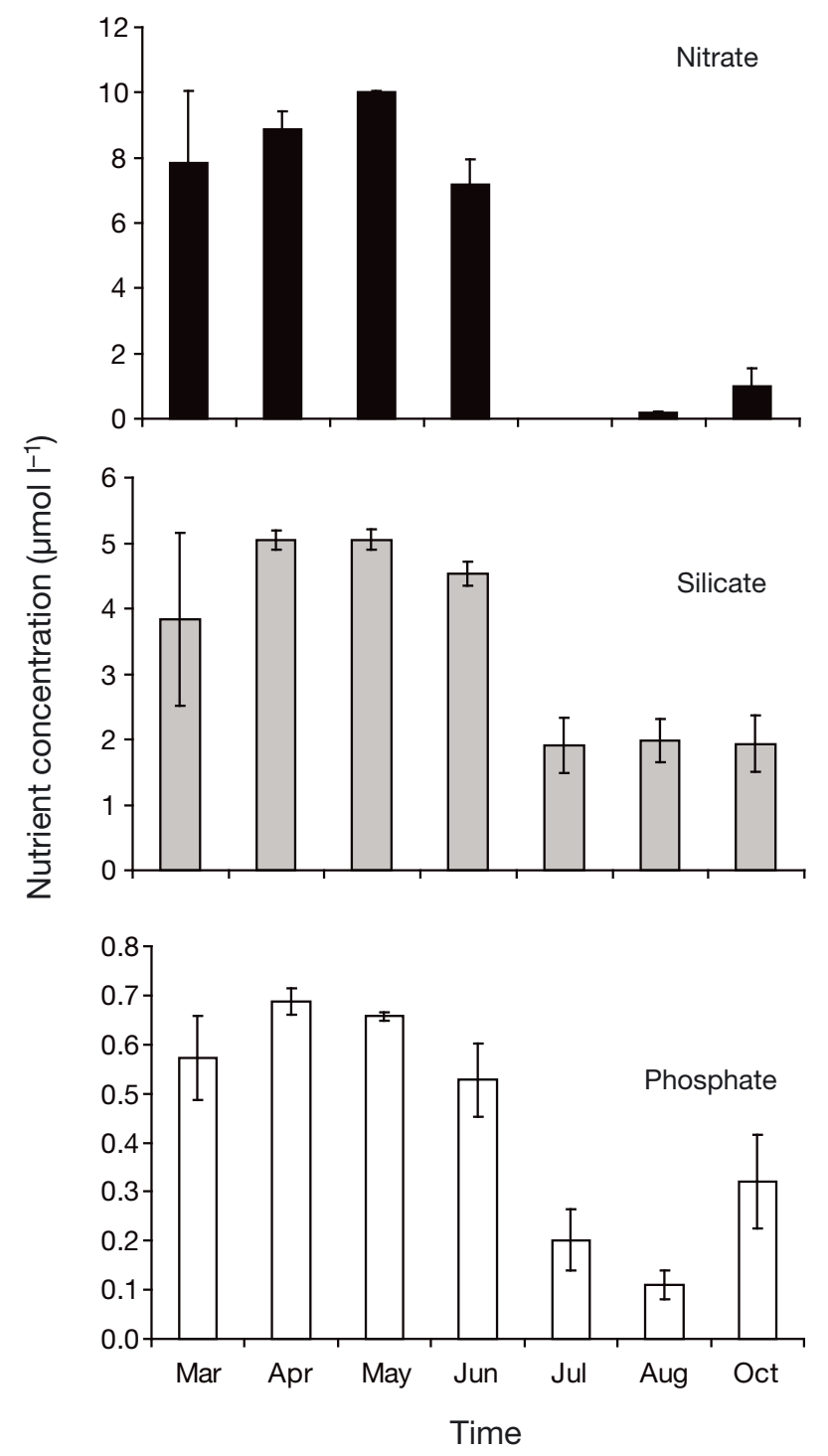

Fig. 4. Surface ( 0 to $1 \mathrm{~m}$ ) water nutrient concentrations. Average values for each month are given $(n=2$ to 8 ; shown are means and SD)

septentrionalis and Fragilariopsis cylindrus were the most abundant species. This dominance was equally strong when expressed as carbon biomass: diatoms accounted then for 76 to $96 \%$ at all times (Fig. 5). Dinoflagellates were the second most important group of protists, accounting for a maximum $23 \%$ of the total carbon biomass. In June, increasing abundances of ciliates were observed; however, they did not exceed $9 \%$ of the biomass. The overall ice algal biomass in terms of particulate carbon did not differ significantly between April and June ( $t$-test, $\mathrm{p}<0.05)$. Chlorophyll a values, however, were on average twice as high in April than those in June (Table 3). Consequently, the chl a:C ratio was significantly lower in June $(t$-test, $\mathrm{p}<$ 
Table 2. Particulate $\mathrm{C}, \mathrm{N}$ and P concentrations from ice algae in the lowermost 5 to $7 \mathrm{~cm}$ of sea ice; molar ratios of elemental stoichiometry; and pigment data (chl $a$ and the ratio between the sum of the photoprotective pigments diadinoxanthin [Dd] and diatoxanthin [Dt] and chl a). Shown are means and SD for 3 replicate cores

\begin{tabular}{|c|c|c|c|c|c|c|c|c|c|}
\hline Site \& date & $\mathrm{C}\left(\mathrm{mg} \mathrm{m}^{-2}\right)$ & $\mathrm{N}\left(\mathrm{mg} \mathrm{m}^{-2}\right)$ & $\mathrm{P}\left(\mathrm{mg} \mathrm{m}^{-2}\right)$ & $\mathrm{C}: \mathrm{N}$ & $\mathrm{C}: \mathrm{P}$ & $\mathrm{N}: \mathrm{P}$ & $\operatorname{chl} a\left(\mathrm{mg} \mathrm{m}^{-2}\right)$ & chl $a: C$ & $(\mathrm{Dd}+\mathrm{Dt}): \operatorname{chl} a$ \\
\hline SH 26 Apr & $241.09 \pm 55.23$ & $20.99 \pm 6.06$ & $5.76 \pm 0.71$ & $13.58 \pm 0.87$ & $108.71 \pm 24.37$ & $8.11 \pm 2.30$ & $19.56 \pm 7.64$ & $0.08 \pm 0.02$ & $0.030 \pm 0.001$ \\
\hline RIB 28 Apr & $99.77 \pm 32.70$ & $7.37 \pm 2.00$ & $3.30 \pm 0.64$ & $15.68 \pm 1.78$ & $77.18 \pm 13.03$ & $4.90 \pm 0.38$ & $10.23 \pm 2.35$ & $0.11 \pm 0.03$ & $0.029 \pm 0.003$ \\
\hline BS 28 Apr & $363.54 \pm 65.84$ & $40.92 \pm 6.22$ & $8.09 \pm 1.77$ & $10.34 \pm 0.74$ & $116.78 \pm 6.47$ & $11.36 \pm 1.38$ & $48.17 \pm 5.75$ & $0.13 \pm 0.02$ & $0.030 \pm 0.001$ \\
\hline SH $30 \mathrm{Apr}$ & $237.67 \pm 50.74$ & $27.75 \pm 4.83$ & $6.60 \pm 0.69$ & $9.96 \pm 0.40$ & $92.48 \pm 10.13$ & $9.27 \pm 0.65$ & $20.65 \pm 1.51$ & $0.09 \pm 0.01$ & $0.030 \pm 0.002$ \\
\hline SH 5 Jun & $340.41 \pm 133.17$ & $31.34 \pm 12.20$ & $7.05 \pm 2.74$ & $12.65 \pm 1.53$ & $124.34 \pm 10.79$ & $9.86 \pm 0.33$ & $17.91 \pm 0.30$ & $0.06 \pm 0.02$ & $0.064 \pm 0.018$ \\
\hline BS(LL) 6 Jun & $450.02 \pm 101.23$ & $45.41 \pm 5.39$ & $6.31 \pm 5.38$ & $11.48 \pm 1.27$ & $107.74 \pm 6.96$ & $10.03 \pm 0.73$ & $22.51 \pm 2.96$ & $0.05 \pm 0.01$ & $0.063 \pm 0.007$ \\
\hline BS(HL) 6 Jun & $99.01 \pm 43.28$ & $6.53 \pm 3.01$ & $1.60 \pm 0.42$ & $17.91 \pm 0.77$ & $153.60 \pm 35.65$ & $8.64 \pm 2.31$ & $0.99 \pm 0.85$ & $0.01 \pm 0.02$ & $0.319 \pm 0.062$ \\
\hline RIB(LL) 7 Jun & $250.58 \pm 17.14$ & $21.05 \pm 1.56$ & $4.99 \pm 0.70$ & $13.92 \pm 1.05$ & $130.76 \pm 13.11$ & $9.48 \pm 1.72$ & $8.48 \pm 1.33$ & $0.03 \pm 0.00$ & $0.080 \pm 0.009$ \\
\hline RIB(HL) 7 Jun & $54.43 \pm 47.92$ & $4.02 \pm 3.55$ & $1.04 \pm 0.91$ & $17.25 \pm 2.53$ & $136.27 \pm 2.11$ & $7.99 \pm 0.98$ & $2.16 \pm 1.74$ & $0.03 \pm 0.02$ & $0.21 \pm 0.101$ \\
\hline
\end{tabular}

Table 3. Stable carbon $\left(\delta^{13} \mathrm{C}\right)$ and nitrogen $\left(\delta^{15} \mathrm{~N}\right)$ values (mean of 3 replicates \pm standard deviation) of ice algae in April and June

\begin{tabular}{|lcc|}
\hline Date & $\delta^{13} \mathrm{C}$ & $\delta^{15} \mathrm{~N}$ \\
\hline $26 \mathrm{Apr}$ & $-23.1 \pm 0.3$ & $3.3 \pm 0.6$ \\
30 Apr & $-21.6 \pm 1.1$ & $4.3 \pm 1.5$ \\
28 Apr & $-21.0 \pm 0.2$ & $3.3 \pm 1.1$ \\
6 Jun & $-17.6 \pm 0.4$ & $4.4 \pm 0.1$ \\
7 Jun & $-17.1 \pm 0.2$ & $5.2 \pm 0.8$ \\
\hline
\end{tabular}

0.001). The ratio of diadinoxanthin and diatoxanthin to chl $a$ also increased in June (Table 3, Mann-Whitney-U test, $\mathrm{p}<0.001)$. Within the June samples, significant differences were found in all variables between HL and LL sites, with lower biomass and lower chl a:C and higher $(\mathrm{Dd}+\mathrm{Dt})$ :chl a ratios in the HL sites (Table 3).

\section{DISCUSSION}

\section{Changes in fatty acid composition and implications for growth and lipid allocation}

The fatty acid composition of sea ice algae in this study was largely dominated by diatom-marker fatty acids, such as 20:5n3, C16 PUFAs and 16:1n7, which was in good agreement with the taxonomic analyses that confirmed the strong dominance of diatom species in the overall algal biomass during the entire sampling period. Total values of PUFAs were highest in April, but their share of total FAs was still lower than the maximum values close to $50 \%$ reported for ice algae in the Barents Sea by Falk-Petersen et al. (1998). Similarly high values were found by Nichols et al. (1993) and McMinn et al. (1999) for ice algae collected in Antarctica. The latter, however, documented a vertical gradient of PUFAs in the ice core, with $50 \%$ PUFAs found only in the lowermost 0 to $2 \mathrm{~cm}$ of ice cores. The relative importance of PUFAs decreased higher up in the core, which was attributed to nutrient limitation (McMinn et al. 1999). Another possible explanation, however, may be the vertical irradiance gradient found within the ice. Since our samples represent an integration over the lowermost 5 to $7 \mathrm{~cm}$, we cannot distinguish a similar vertical gradient in nutrient limitation and, hence, food quality. This may be one reason why our values seem to be lower. The high PUFA content described by Falk-Petersen et al. (1998) stems from ice algae samples collected by scuba divers, and therefore these samples come from the lowermost ice algae layer that is relatively loosely attached to the ice and thus has good access to a fresh nutrient supply from the water column. Our data indicate a pronounced decrease of nutritional quality (measured as \% PUFAs) in sea ice algae over time. At the same time, the relative importance of 16:1n7 increased strongly. The only other study that followed the development of sea ice algal fatty acid composition over time spanned only 3 wk and did not find similarly clear trends of change (Nichols et al. 1993). High amounts of 16:1n7 are usually found in TAGs (storage lipids) (Falk-Petersen et al. 1998, Henderson et al. 1998), and their relative amount can increase as a consequence of N-limitation (Mock \& Kroon 2002a, E. Leu unpubl. data). Towards the end of the sea ice algae bloom, an increased relative allocation of photosynthate to lipids is seen (Lee et al. 2008), as well as an increase of neutral (storage) lipids at the expense of polar (structural) lipids (Smith et al. 1993, 1997). Since PUFAs are mostly found in structural lipids that again are the major lipid class during favorable growth conditions, our results fit well into that picture. Microscopic analyses of sea ice algae from Rijpfjorden revealed furthermore the occurrence of droplets that probably represent storage lipids in diatoms sampled in June, but not in April. Contrary to these field data, experimental studies by Mock \& Gradinger (2000) showed no increase in storage lipids, but a dominance of glycolipids under decreasing nutri- 


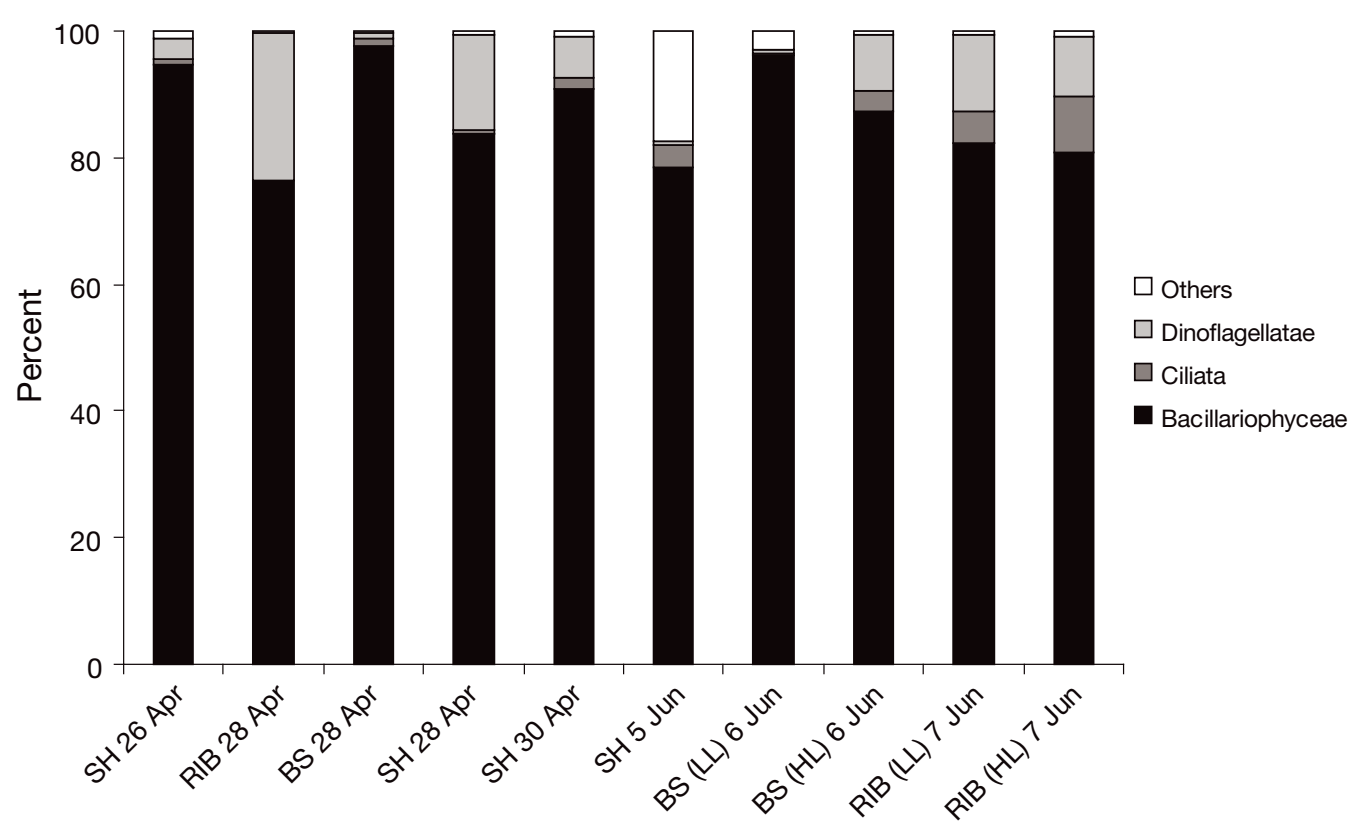

Fig. 5. Relative carbon biomass of the major taxonomic groups of sea ice protists. Shown are average values from 3 replicate ice cores

ent concentrations. Since we did not analyse lipid classes in our samples, a direct comparison with our data is not possible. However, since we observed a clear drop in chl $a$ :C ratios from April to June, it seems unlikely that glycolipids (as the dominating lipid class in chloroplasts) were higher in June than April.

Potential reasons for an increased allocation of photosynthetically fixed carbon to neutral (storage) lipids can be nutrient limitation (Lizotte \& Sullivan 1992), increased irradiance (Smith et al. 1989), or generally the transition to the stationary growth phase. In particular, a lack of silicate has been proven to increase the lipid content of diatoms substantially (Taguchi et al. 1987). Although the nutrient concentrations in surface water in June were still not markedly reduced compared with those in April, the local availability of silicate for sea ice algae may have been limited after a continuous bloom period of several weeks. It is important to note that the observed decrease of nutritional quality took place without any significant changes of average biomass in terms of particulate $C$.

Algal stable isotope ratios showed a correspondingly strong change for carbon from April to June. A similar increase in ${ }^{13} \mathrm{C}$ in ice algae was found by Søreide et al. (2006a) when comparing ice algae in good versus poor condition. As discussed for fatty acid composition, taxonomic changes can be excluded as a potential source for this change. Higher abundances of heterotrophic ciliates were found in June than in April. Their overall contribution to biomass, however, was low (ranging from 3 to $9 \%$ in June), which the comparatively low $\delta^{15} \mathrm{~N}$ values of ice algae in April and June also confirmed. The large variability in sea ice algae $\delta^{13} \mathrm{C}$ values is problematic for the use of stable $\mathrm{C}$ isotope ratios in food web studies (Søreide et al. 2006a, Gradinger 2009). Hence, a better understanding of the underlying causes is of great interest. Changes in the carbon isotopic composition of ice algae may reflect changes in the isotopic composition of $\Sigma \mathrm{CO}_{2}$ in closed or semi-closed environments where replenishment of $\Sigma \mathrm{CO}_{2}$ from either atmospheric or advective exchange are limited (Kennedy et al. 2002). Arrigo et al. (2003) and Tremblay et al. (2006) found a strong positive relationship between ice algal $\delta^{13} \mathrm{C}$ values and sea ice thickness. In our study, ice algal $\delta^{13} \mathrm{C}$ values changed profoundly, although the sea ice thickness remained largely unaltered between April and June. A strong positive correlation has also been found between ice algae $\delta^{13} \mathrm{C}$ values and ice algal biomass (Tremblay et al. 2006) but could not be confirmed by us. We therefore argue that rather potential changes in $\delta^{13} \mathrm{C}_{\mathrm{\Sigma CO} 2}$ combined with changes in light and ice algal growth and energy allocation over time account for some of the large variability observed in ice algae $\delta^{13} \mathrm{C}$ values. Apart from nutrient limitation as one major factor affecting ice algal growth and ice algae stable isotope composition (e.g. (Kennedy et al. 2002), light, as shown in this study, directly affects growth conditions and the biochemical composition of sea ice algae. In fact, in Rijpfjorden light rather than nutrients seemed to be more decisive in explaining some of the ${ }^{13} \mathrm{C}$ enrichment in sea ice algae since differences in nutrient concentrations were small between April and June. 


\section{Environmental conditions as steering factors (light versus nutrients)}

Biochemical changes in ice algae have usually been attributed to either light conditions and/or nutrient supply, with differing conclusions about the importance of these two (see, e.g. Lizotte \& Sullivan [1992], Smith et al. [1993]). The most common view is that ice algal blooms in their early phase are mostly limited by light availability and later reach a stage at which nutrient depletion regulates predominantly their growth conditions (Gosselin et al. 1990). Due to the complex microstructure of the ice, however, it is extremely difficult to obtain realistic in situ measurements of both factors. The use of indirect indicators for nutrient depletion, for example, in terms of elemental ratios between $\mathrm{C}: \mathrm{N}$ or $\mathrm{C}: \mathrm{P}$ also requires some caution, since these ratios are influenced by both light and nutrient availability (Sterner \& Elser 2002).

Light, or more precisely, transmittance, was the environmental driver that explained best the changes in algal fatty acid composition observed during our study (Fig. 3). It has been described before that high irradiances can be detrimental for the relative amount of PUFAs in phytoplankton (Thompson et al. 1990, Leu et al. 2006a, b). As mentioned above, the early phase of an ice algal bloom, however, is usually characterized by light limitation rather than excess radiation (Gosselin et al. 1990). Under light-limiting growth conditions, a higher degree of unsaturated fatty acids in thylakoid membrane lipids can be found as a physiological adaptation (Mock \& Kroon 2002b). In the current study, 3 groups of samples could be clearly distinguished with respect to their fatty acid composition (Fig. 3). Highest amounts of PUFAs were found in the earliest samples, and increasing irradiance was strongly negatively correlated with these essential fatty acids. Sea ice algae showed furthermore several clear indications of a progressive adaptation to higher irradiances, when starting from algae sampled in (1) April, to the samples (2) taken under high snow cover (LL-site) in June, all the way to (3) the samples being exposed to highest irradiances (HL-site) in June. These 3 groups of samples differed significantly in their chl a:C ratios (decreasing with increasing irradiances), as well as their content of photoprotective pigments relative to $\mathrm{chl} a$ (increasing with increasing irradiances).

A concomitant increase was found in algal C:N and $\mathrm{C}: \mathrm{P}$ ratios from April to June. Even though increased irradiances typically also lead to an increase of those ratios (Sterner \& Elser 2002), these changes might indicate a growing nutrient limitation, at least in the case of nitrogen. N:P ratios of 9 are only $50 \%$ of what should be expected under non-limiting conditions (Sterner et al. 2008). C:N and N:P ratios from the entire sampling
Table 4. Results from correlation analyses between different environmental factors and the algal content of polyunsaturated fatty acids (PUFAs) and C:N ratios. r: Pearson linear correlation coefficients. Dd: diadinoxanthin; Dt: diatoxanthin

\begin{tabular}{|lrl|}
\hline & \multicolumn{2}{c|}{ PUFA } \\
& $\mathrm{r}$ & $\mathrm{p}$ \\
\hline Ice thickness & 0.449 & $0.036^{*}$ \\
Transmittance & -0.739 & $0.000^{*}$ \\
$\mathrm{C}: \mathrm{N}$ & -0.351 & 0.109 \\
chl $a: \mathrm{C}$ & 0.831 & $0.000^{*}$ \\
(Dd + Dt):chl a & -0.710 & $0.000^{*}$ \\
\hline
\end{tabular}

period indicate that nitrogen supply was not optimal, although nitrate concentrations in surface waters were high and should be available for a substantial part of the bottom ice algae community. In sub-ice assemblages from first year ice in the Barents Sea dominated as well by Nitzschia frigida, C:N ratios between 7 and 10 were found in late May (Hegseth 1992). An increase in $\mathrm{C}: \mathrm{N}$ ratios from 8 to over 20 was seen in sea ice algae in the Canadian Arctic over the same period (April to mid-June, April to mid-May, respectively) (Gosselin et al. 1990), indicating a much more severely limited situation than the one found in our study. For the current study, it is important to note that C:N ratios taken at LL and HL sites at the same stations in June (i.e. being exposed to identical ice thickness and nutrient concentrations in surface water) differed strongly. Hence, irradiance has to be the underlying factor causing those differences.

To further clarify the relative importance of light and nutrient availability for the observed changes in $\%$ PUFAs, correlation analyses were carried out (Table 4). The results show no significant correlation between C:N ratios and \% PUFAs, while a strong negative correlation was found between transmittance and $\%$ PUFAs in sea ice algae $(\mathrm{r}=-0.74 ; \mathrm{p}<0.0001)$. Strong significant correlations between chl a:C and $(\mathrm{Dd}+\mathrm{Dt})$ :chl a ratios with \% PUFAs furthermore underlined the dominating influence of irradiance on the biochemical composition of the algae.

\section{Further implications of changed snow cover}

The remarkable variation of algal biomass between sites exposed to high or low irradiances in June are in line with the findings by Mundy et al. (2005), showing that snow cover is by far the most important variable determining the physical environment for sea ice algae. They also noted that low snow cover (= high irradiance exposure), especially late in the season, led to a decrease of ice algal biomass due to loss of thermal 
insulation and sloughing of algae. This might explain the significantly lower biomass values of sea ice algae found on sampling sites with little snow cover on top in June than in those sites that still were covered by up to $20 \mathrm{~cm}$ of snow. Our results indicate furthermore the profound biochemical changes that these algae are undergoing as a response to the seasonal progression of snow and ice conditions.

\section{CONCLUSION}

We conclude that light is a major factor affecting the nutritional quality of sea ice algae. Our results furthermore underline the plasticity of both FA composition and stable isotope signature of sea ice algae, depending on growth conditions and physiological state. Their highest nutritional value is found earliest in the season, when usually no other primary producers are present. Although ice algae in general do not necessarily have a higher nutritional value than phytoplankton, their ecological significance is still high because they provide high-quality food so early in the season.

Acknowledgements. We gratefully acknowledge the help during field work by H. Nygård and M. Vihtakari. We also thank S. Kristiansen for nutrient analyses, A. Wulff for the analysis of photosynthetic pigments, A. Tatarek for help with the taxonomic analyses, and D. O. Hessen for providing us with data on elemental stoichiometry. The manuscript profited from the constructive comments by 3 anonymous reviewers. This study was funded by the Norwegian Research Council (Project nr. 178766/S30) as part of the Norwegian contribution to the International Polar Year (IPY) 2007 to 2009.

\section{LITERATURE CITED}

Ambrose WG, Carroll ML, Greenacre M, Thorrold SR, McMahon KW (2006) Variation in Serripes groenlandicus (Bivalvia) growth in a Norwegian high-Arctic fjord: evidence for local- and large-scale climatic forcing. Glob Change Biol 12:1595-1607

Arrigo KR (2003) Primary production in sea ice. In: Thomas DN, Dieckmann GS (eds) Sea ice: an introduction to its physics, chemistry, biology and geology. Blackwell Publishing, Oxford, p 143-183

Arrigo KR, Robinson DH, Dunbar RB, Leventer AR, Lizotte MP (2003) Physical control of chlorophyll a, POC, and TPN distributions in the pack ice of the Ross Sea, Antarctica. J Geophys Res 108, 3316 doi:10.1029/2001JC001138

Arrigo KR, van Dijken G, Pabi S (2008) Impact of a shrinking Arctic ice cover on marine primary production. Geophys Res Lett 35,L19603 doi:10.1029/2008GL035028

Christie WW (ed) (1982) Lipid analysis: isolation, separation, identification, and structural analysis of lipids, 2nd edn (rev). Pergamon Press, New York

> Comiso JC, Parkinson CL, Gersten R, Stock L (2008) Accelerated decline in the Arctic Sea ice cover. Geophys Res Lett 35,L01703 doi:10.1029/2007GL031972

Conover RJ, Herman AW, Prinsenberg SJ, Harris LR (1986)
Distribution of and feeding by the copepod Pseudocalanus under fast ice during the Arctic spring. Science 232: 1245-1247

Cota GF, Legendre L, Gosselin M, Ingram RG (1991) Ecology of bottom ice algae: I. Environmental controls and variability. J Mar Syst 2:257-277

$>$ Falk-Petersen S, Sargent JR, Henderson J, Hegseth EN, Hop H, Okolodkov YB (1998) Lipids and fatty acids in ice algae and phytoplankton from the Marginal Ice Zone in the Barents Sea. Polar Biol 20:41-47

> Folch J, Lees M, Sloane Stanley GH (1957) A simple method for isolation and purification of total lipids from animal tissue. J Biol Chem 226:497-509

- Fry B (1996) C-13/C-12 fractionation by marine diatoms. Mar Ecol Prog Ser 134:283-294

Gosselin M, Legendre L, Therriault JC, Demers S (1990) Light and nutrient limitation of sea-ice microalgae (HudsonBay, Canadian Arctic). J Phycol 26:220-232

Gosselin M, Levasseur M, Wheeler PA, Horner RA, Booth BC (1997) New measurements of phytoplankton and ice algal production in the Arctic Ocean. Deep-Sea Res II 44: 1623-1644

> Gradinger R (2009) Sea-ice algae: major contributors to primary production and algal biomass in the Chukchi and Beaufort Seas during May/June 2002. Deep-Sea Res II 56: 1201-1212

> Hegseth EN (1992) Sub-ice algal assemblages of the Barents Sea: species composition, chemical composition, and growth rates. Polar Biol 12:485-496

> Henderson RJ, Hegseth EN, Park RT (1998) Seasonal variation in lipid and fatty acid composition of ice algae from the Barents Sea. Polar Biol 20:48-55

Hessen DO, Faerovig PJ, Andersen T (2002) Light, nutrients, and $P: C$ ratios in algae: grazer performance related to food quality and quantity. Ecology 83:1886-1898

> Hobson KA, Welch HE (1992) Determination of trophic relationships within a high Arctic marine food web using delta-C-13 and delta-N-15 analysis. Mar Ecol Prog Ser 84:9-18

> Hobson KA, Ambrose WG, Renaud PE (1995) Sources of primary production, benthic-pelagic coupling, and trophic relationships within the Northeast Water Polynya: insights from delta C-13 and delta N-15 analysis. Mar Ecol Prog Ser 128:1-10

Johnsen G, Hegseth EN (1991) Photoadaptation of sea-ice microalgae in the Barents Sea. Polar Biol 11:179-184

Jonasdottir SH, Trung NH, Hansen F, Gartner S (2005) Egg production and hatching success in the calanoid copepods Calanus helgolandicus and Calanus finmarchicus in the North Sea from March to September 2001. J Plankton Res 27:1239-1259

Jonasdottir SH, Visser AW, Jespersen C (2009) Assessing the role of food quality in the production and hatching of Temora longicornis eggs. Mar Ecol Prog Ser 382:139-150

Kennedy H, Thomas DN, Kattner G, Haas C, Dieckmann GS (2002) Particulate organic matter in Antarctic summer sea ice: concentration and stable isotopic composition. Mar Ecol Prog Ser 238:1-13

Lee SH, Whitledge TE, Kang SH (2008) Spring time production of bottom ice algae in the landfast sea ice zone at Barrow, Alaska. J Exp Mar Biol Ecol 367:204-212

Legendre P, Legendre L (1998) Numerical ecology. Elsevier Science, Amsterdam

> Leu E, Falk-Petersen S, Kwasniewski S, Wulff A, Edvardsen K, Hessen DO (2006a) Fatty acid dynamics during the spring bloom in a High Arctic fjord: importance of abiotic factors versus community changes. Can J Fish Aquat Sci 63:2760-2779 
Leu E, Wangberg SA, Wulff A, Falk-Petersen S, Orbaek JB, Hessen DO (2006b) Effects of changes in ambient PAR and UV radiation on the nutritional quality of an Arctic diatom (Thalassiosira antarctica var. borealis). J Exp Mar Biol Ecol 337:65-81

Leu E, Falk-Petersen S, Hessen DO (2007) Ultraviolet radiation negatively affects growth but not food quality of arctic diatoms. Limnol Oceanogr 52:787-797

Lizotte MP, Sullivan CW (1992) Biochemical composition and photosynthate distribution in sea ice microalgae of McMurdo Sound, Antarctica: evidence for nutrient stress during the spring bloom. Antarct Sci 4:23-30

Maslanik JA, Fowler C, Stroeve J, Drobot S, Zwally J, Yi D, Emery W (2007) A younger, thinner Arctic ice cover: increased potential for rapid, extensive sea-ice loss. Geophys Res Lett 34,L24501 doi: 10.1029/2007GL032043

McMinn A, Skerratt J, Trull T, Ashworth C, Lizotte M (1999) Nutrient stress gradient in the bottom $5 \mathrm{~cm}$ of fast ice, McMurdo Sound, Antarctica. Polar Biol 21:220-227

Menden-Deuer S, Lessard EJ (2000) Carbon to volume relationships for dinoflagellates, diatoms, and other protist plankton. Limnol Oceanogr 45:569-579

Michel C, Legendre L, Ingram RG, Gosselin M, Levasseur M (1996) Carbon budget of sea-ice algae in spring: evidence of a significant transfer to zooplankton grazers. J Geophys Res 101:18345-18360

Mock T, Gradinger R (2000) Changes in photosynthetic carbon allocation in algal assemblages of Arctic sea ice with decreasing nutrient concentrations and irradiance. Mar Ecol Prog Ser 202:1-11

Mock T, Kroon BMA (2002a) Photosynthetic energy conversion under extreme conditions - I: important role of lipids as structural modulators and energy sink under N-limited growth in Antarctic sea ice diatoms. Phytochemistry 61: 41-51

Mock T, Kroon BMA (2002b) Photosynthetic energy conversion under extreme conditions-II: the significance of lipids under light limited growth in Antarctic sea ice diatoms. Phytochemistry 61:53-60

Mock T, Thomas DN (2005) Recent advances in sea-ice microbiology. Environ Microbiol 7:605-619

Muller-Navarra DC (2008) Food web paradigms: the biochemical view on trophic interactions. Int Rev Hydrobiol 93:489-505

Mundy CJ, Barber DG, Michel C (2005) Variability of snow and ice thermal, physical and optical properties pertinent to sea ice algae biomass during spring. J Mar Syst 58: 107-120

Nichols DS, Nichols PD, Sullivan CW (1993) Fatty acid, sterol and hydrocarbon composition of Antarctic sea-ice diatom communities during the spring bloom in McMurdo Sound. Antarct Sci 5:271-278

Post DM (2002) Using stable isotopes to estimate trophic position: models, methods, and assumptions. Ecology 83: 703-718

Reitan KI, Rainuzzo JR, Olsen Y (1994) Effect of nutrient limitation on fatty acid and lipid content of marine microalgae. J Phycol 30:972-979

Reuss N, Poulsen LK (2002) Evaluation of fatty acids as biomarkers for a natural plankton community. A field study of a spring bloom and a post-bloom period off West Greenland. Mar Biol 141:423-434

Runge JA, Ingram RG (1988) Underice grazing by planktonic, calanoid copepods in relation to a bloom of ice microalgae in southeastern Hudson Bay. Limnol Oceanogr 33: $280-286$

Editorial responsibility: Andrew Brierley, St. Andrews, UK
Rysgaard S, Nielsen TG (2006) Carbon cycling in a higharctic marine ecosystem-Young Sound, NE Greenland. Prog Oceanogr 71:426-445

Skerratt JH, Nichols PD, McMeekin TA, Burton H (1995) Seasonal and inter-annual changes in planktonic biomass and community structure in eastern Antarctica using signature lipids. Mar Chem 51:93-113

Smith REH, Clement P, Cota GF, Li WKW (1987) Intracellular photosynthate allocation and the control of Arctic marine ice algal production. J Phycol 23:124-132

Smith REH, Clement P, Head E (1989) Biosynthesis and photosynthate allocation patterns of Arctic ice algae. Limnol Oceanogr 34:591-605

> Smith REH, Cavaletto JF, Eadie BJ, Gardner WS (1993) Growth and lipid composition of high Arctic ice algae during the spring bloom at Resolute, Northwest-Territories, Canada. Mar Ecol Prog Ser 97:19-29

Smith REH, Gosselin M, Taguchi S (1997) The influence of major inorganic nutrients on the growth and physiology of high arctic ice algae. J Mar Syst 11:63-70

Søreide JE, Hop H, Carroll M, Falk-Petersen S, Hegseth EN (2006a) Seasonal food web structures and sympagicpelagic coupling in the European Arctic revealed by stable isotopes and a two-source food web model. Prog Oceanogr 71:59-87

Søreide JE, Tamelander T, Hop H, Hobson KA, Johansen I (2006b) Sample preparation effects on stable C and N isotope values: a comparison of methods in Arctic marine food web studies. Mar Ecol Prog Ser 328:17-28

Søreide JE, Leu E, Berge J, Graeve M, Falk-Petersen S (2010) Timing of blooms, algal food quality and Calanus glacialis reproduction and growth in a changing Arctic. Global Change Biol (in press)

Sterner RW, Elser JJ (2002) Ecological stoichiometry. Princeton University Press, Princeton, NJ

Sterner RW, Andersen T, Elser JJ, Hessen DO, Hood JM, McCauley E, Urabe J (2008) Scale-dependent carbon: nitrogen:phosphorus seston stoichiometry in marine and freshwaters. Limnol Oceanogr 53:1169-1180

Stroeve JC, Serreze MC, Fetterer F, Arbetter T, Meier W, Maslanik J, Knowles K (2005) Tracking the Arctic's shrinking ice cover: another extreme September minimum in 2004. Geophys Res Lett 32,L04501 doi: 10.1029/ 2004GL021810

Taguchi S, Hirata JA, Laws EA (1987) Silicate deficiency and lipid synthesis of marine diatoms. J Phycol 23:260-267

ter Braak CFJ, Smilauer P (2002) CANOCO reference manual and CanoDraw for Windows user's guide: software for canonical community ordination (version 4.5). Microcomputer Power, Ithaca, NY

Thompson PA, Harrison PJ, Whyte JNC (1990) Influence of irradiance on the fatty acid composition of phytoplankton. J Phycol 26:278-288

Tourangeau S, Runge JA (1991) Reproduction of Calanus glacialis under ice in spring in southeastern Hudson Bay, Canada. Mar Biol 108:227-233

Tremblay JE, Michel C, Hobson KA, Gosselin M, Price NM (2006) Bloom dynamics in early opening waters of the Arctic Ocean. Limnol Oceanogr 51:900-912

Utermöhl H (1958) Zur Vervollkommnung der quantitativen Phytoplankton Methodik. Mitt Int Ver Limnol 9:1-38

Wallace MI, Cottier FR, Berge J, Tarling GA, Griffiths C, Brierley AS (2010) Comparison of zooplankton vertical migration in an ice-free and a seasonally ice-covered Arctic fjord: an insight into the influence of sea ice cover on zooplankton behaviour. Limnol Oceanogr 55:831-845 